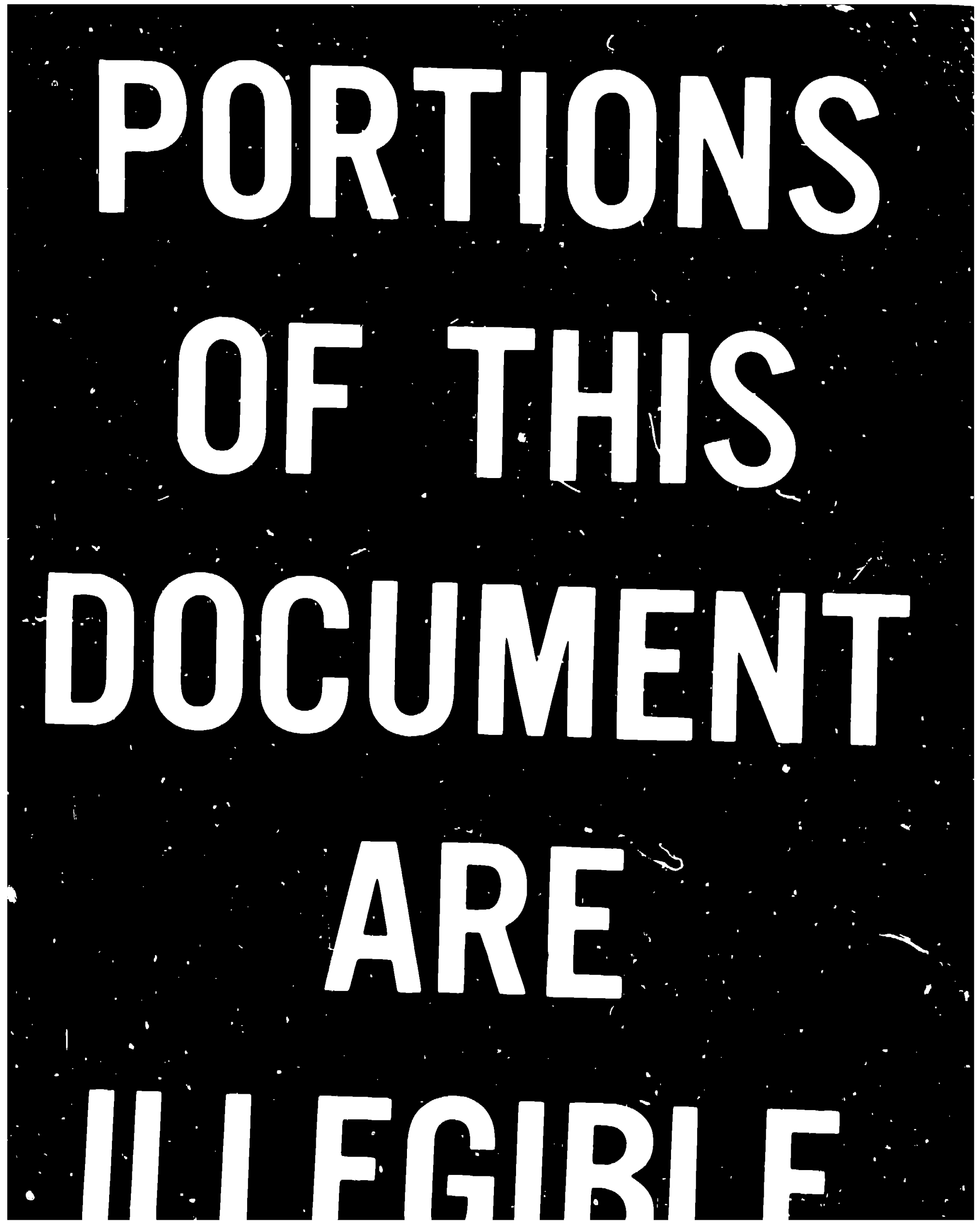


LA-UR -82-543

$$
(2.6-3,20.524--4
$$

\section{MASTER :}

TITLE TRACER EXPERIMENTS IN EASTERN DEVONIAN SHULE

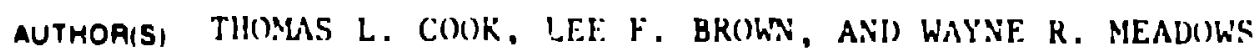

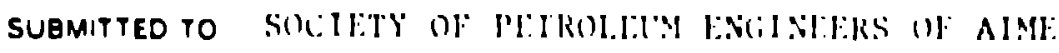

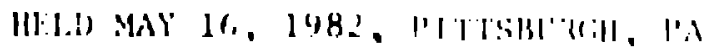


TRACER EXPERIMENTS IN EASTERN DEVONIAN SHALE

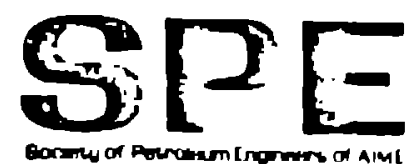

T. L. COOK, L. F. BROWN AND W. R. MEADOWS

EARTH AND SPACE SCIENCE DIVISION

GEUANALYSIS GROUP, ESS-5

LOS ALAMOS NATIONAL LABORATORY

\section{ABSTKACI}

For the purpose of characterlalng the propertlec of the Eastern Devondan gas chaje. a ceven-day tracer experiment was carried oul in Augut of 1981 by the Los Alamo. National Laboratory a part of the DOC. offser-inell test. Two wells had been drilled in a Coluobla Gas Company lield in southeastern Ohio, ach with a downole separation of epproxloutely 120 leet frow an exiecing production vel?. The louceles triangle formed by the chree vells had an apex angle of approximately 110 degrees. About 36,000 SC.F of nitrogen were injected into e producing zone located at a depth of 3300 fert in one of the wella. Gas was thell produced from the verious velle at different ratow and preseures for the duration of the teat. Both preseure and bas composition in the three velle were conttored choughout the teet.

\section{INTRODUCTION}

The efficlent recovery of sethane frum any ight formations austes the lopletientation of ingroved climulation techninues. Deteralnation of the enproprlace aechod can be anatued by a better understonding of the opthane ciorage and iransport wlihin ll.e rock. It was to how how thle better underetanding can be aitelned thel the los Alabis Natlonal Laboralory caicled out a even-day iracer experinent in en eavern cae fleld as part of the Depertaent of Energy' oflaet Hell teat.

The gas In the fi-ld teaced ts held in Devonian -hele. Seructurally, thene eheles conetet of low porosicy cetrix plerced ehroughout by complex nelwr b of fractures cenerally vertical reialive to the horleosial beddlng plenea. A'though eethene gas hes been produced fros nevoniso ohales in the

References end llluapretione at end of paper.

Work Firfored inder the aueplies of the us Dot, Morganion Tenerey Technolony Center. K.-H. Troline, Tochingal Project officer.
Appajachion Basin for wore than fifty years, there 15 at1l a vide range of opinion concerning the nature of the underground torage of the gas. Stlmulatior. aethode for production welle vary, depending an whether the wethane 1 s cored in the pores or $1 \mathrm{n}$ the fracturea. Joe of the purposes of the tracer teat was to deterrolne the relative amounts of gar in the different corage cedia.

The ceot was based on a concepl originaliy proposed by Lincoln $F$. Elkint of Sohlo oll Con; an: It uaed an old orthane weil, which continues to bi a uneful production well even after elgheen years of llow. In oddition, the experisent erpluyed two new velin drllied near the production well a part of the DOC. Offaet Well Test. In Elklns. concept, tracer or iracers vould be injected into one of I' vells, and then this well back-produced. The concentration-ilwe behevior of the irecers in llie vell eflluent would give inforbation concerndng tir ecorage characterialica of the gea in the ohale.

In our teet, we Injected 36,000 sct of nltrofen Into one of the new wells and eubsequently beckproduced this injection vell. The old production vell and the eacund new well were allowed to flow at reles euificlent for chemical analyala. Racen vere andince higher clian this, due to leakn, but the ecential flow rases for all lines could be calculeted. Sperlea-concentralluh and prennife data vere cullected at all ehree velle chrouphous the teot.

DACXrROUNU TO EXPLRIMENT Geolosy

Iraed Intercontinental eeas depueted clie eedieents thet wake up the alddle and luper Devonlan ohales of ohlo. Deocending froe the eurfuce, tie lievonten thale Inyere thet occur in eoutheneter" olilo are the Cleveland Monher, the Chargln Mectier. and the Huron Menher. The Hurun Menher le dark-eray to bleck in color and to the mat hichly orgentc of the hilo Shalea. The gaseprodurlne cones ere found in ihts letter moher. The Huron shale te cunpuned piliontly of elle, clay. end carbunacenue encer. The layer conealne nelvork of linteriennected verifical 
fractures. For the Hurca ilemer in Meigo Councy, wiere the test was performad, che hlghest frequency of parallel fractures has a NS $0^{\circ} \mathrm{E}$ to $N 60^{\circ} \mathrm{E}$ trend.

\section{Configurat ion}

Two wello were drilled near a produclng fethane well, which is offlelally reglatered as Hell 10050. Well 10056 1. referred to $A$ Well $C$ in elie remalnder of this report. Well A was of set irod Weld $C$ in ditection paraliel to the primary fracture trend described above. Well B was of fuet : row Well C Ir. direction approximately perpendicular to the trend. Figure : chows the orlentation and downhole beparation of the three welle. The angle ACB 18 about $110^{\circ}$ and the distarices $\mathrm{AC}$ and $\mathrm{CB}$ are $118 \mathrm{ft}$.

Each well was drilled co a cotal depch of about $3500 \mathrm{ft}$, wh!ch 1s near the base of the Huron Member. The anor gas projucing zone lies in the lncerva BS-115 ft above the $3400 \mathrm{ft} l$ guel in ielle $A$ and $C$. From presaure bulld-up ecets", we conclude that bell $B$ is not in ciose comounlcat 1 on with Wells $A$ and $C$.

Figure 2 summarizes the liole conflguration in each well. Well C hus e total depth of $3400 \mathrm{ft}$. The wall la cased to depth of $2120 \mathrm{ft}$ and has diaweter of 7 incher. Below this level the hale is uncased, having a nominal $61 / 4 \mathrm{I}$. diaweter. The lower 200 ts af the well was sho: loaded uteh nleroglycerln to enhance comminlcalion witi the natural fracture network. Steel tublng having an Inslde diameler of $2.051 \mathrm{n}$. wab linseried from the curface 10 a depih of $3400 \mathrm{ft}$. Thie lover $100 \mathrm{ft}$ of the tublng Is slocted to allow gas flow inco the - tring. Figure 2b bhow an enlarged slez of the lower lio li of well C. A dounhole presfure package a.j supporting vire cable are aleo ehown.

Wello $A$ and have $8 \mathrm{in}$. didmeters and are cased to deflth of 2100 ft. The cotal bepth of wedl A 1. 348: ft: of Hell B, 3478 ft. A rarker vas set

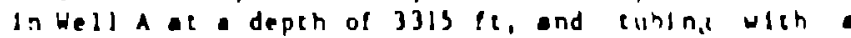
diameler of $2.05 \mathrm{ln}$. was inserted frun $\mathrm{l} h$. eurlace through the center of the packer. No cenira: tublng etring was lnaprled Inea bell B. Flgurea 20 and $2 d$ - how dounlingle pipe configuratione for tiplia $A$ and $B$, renperilively.

Inatrument at Ion

The experlaent conolaced of two prificipel phenes: en Inferiton phane and anck-prduction phare, both lopleconted at Hell A. Premsute and conceniralion tlare hiscorles vere enacured el vericua locations throughoul the teat. The Inltiel and bexpllary condieloma vere carefully eolected and

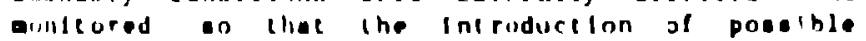
athlgultien in the daca could be elnleleed. It wae fele that the unamblguloue Interptetation o! the reaultu raqulred ant imoue Infectlon phase. Thle 14. If Injection ure interrupied for cone reasun ar another, would proceed lemediately to ber's productlon, phane 2 . Lngletlcal errangenente perolted the unlmerruled infectlot. of $\mathrm{N}_{2}$ for $9-3 / 4$ hire al a cometant vellliead preasure of 630 pel.

Thle preanure whe oplected fur three reasione Hilul, ll llea vell belou the virgla reaervole prensure before drilling (Boo pel) elid vemld

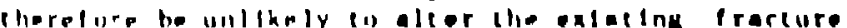
nefuork. Second, le lipe ouffletently obcive the shut-in pressure ( 400 pei) of the reservoli to force the tracer gas into the pore opace, If ouch atorage potential exists. Third, 1t ilef bafely below tine maximum prisbure-differential constralnts of tie packer, et in well a to loolate the major gas-producing zone. Based on pressure and temperasure data and on the respective $N_{2}$ tuoe traller volumes, the cotal amount of $N_{2}$ injected was calculated to be $56,000 \mathrm{SCF}$.

at the acart of phase 2 , Well A was back-produced through a preasure regula:or. When the preacure at ihe vellhead had dronped to 100 ps1, the regulator was adjusted to waincaln thls presaure for tive remainder of the tect. A amall amount of $B a s$ ( 80 SCFH) was druwn of and run through the sampling lines of the Las Alawo inserument traller. The experidental plan called for the flow it wells $C$ and $B$ to be rescricted to 80 SCFH; however, this $t$ undary condition was not fulfllled bccause of a low leak cround a coupling near the base of the Well $B$ chrlocmas tree and because of a profusely and -poradically leaklng rubber ceal at hiell C. A compreced $\mathrm{N}_{2}$-driven greacer uas on locet tor at hell $C$ to prevent the leak, but the grease oeal wis ureached several claes during the cesc. From the data behavior, the $f$ lno ratos fron well $C$ durlng th: laak perludo can be calculated with recsonable accuracy. The leak at Well b wa content and while not quantillable frow ceculed daca, le offess no real hindrance to our final linterpretations because of the relatively lou level of reservole interaction a B. These matcero are discused in che daca-aumary -ection be low.

The computer-controlled, deta-collection syster wa housed in a Los Alawos incirument craller. The 32-fe orandard traller uan blocked and crlbbed ar a locecton olduay botueen wells a and B. An HP-98js computer activaled the gat oupling eyserto and recorded preasures. The oyecer extracted gas wastes from each we thead in seaggered equenre or $1 \mathrm{n}$ eny order requested by the opuracor. The alninun time required for a particular masple co be sinlyzed by the gas chrowetograph was eunty alnuces; 0 if al! three wells vere belng analyzed, each vell was eapled once ivery hour. Aliernatively. alven well could be ecapied three tians every hour if the operator oo denired. The HP-983A gan chroiltiptaph analyzed the production saees and recorded the dica on a floppy diec. A herd copy of the ale was aleo wde on a dats loger

The traller way connected to the vells with holf-lich copjer tublng, walng the extating flttingw at the vallhendo. Rellef volver outalde the traller prolecteo 1te cyeter frun the back-flow of lilgh preseure gae true tha wella. All tublng Inolde clic traller wasetelnlese eceel. In addition to tlip in eaple leken, Ix Independent proseure manureroenc. vere recorded by ille HP-983s every eventy elnuten. One preasure creneducer wes loceted in ench of the wollheads and one in the ennulue of Well a for the duretion il the teet. The flfth eranaducer uno uned In the lube traller Injection line durlne phese 1 . The elath Iransducer uas ueed part of the time in the hack-llor line bf Hell 1 ee e efely feature. providing a cene for Identlyline excenelve proseure bulld-up. 
The Morgantown Ene:gy Technology Cencer recorded downhole pressures in Welle $A$ and $B$, uaing two Amerada RPG-3 gauges for continuous pressure ocribing. The gauge placed in well b had a 180-hr clork and a peak pressure range of 1000 paiz. The ga ied in well a had a 144-hr clock and a axiroum preb. range of 1500 polg. The gauges were pulled from $a$. holes aldway through the cest, so the clocks could br euound, and were then relnserted. These preasure wasurement vere used as a check on the wellhead presiurea we recorded.

\section{EXPERIMENTAI H SULTS}

\section{Preceure daca}

The wellhead preouree for the chree wells throughout the test are presented in Fig. 3. As wentloned earlier, downhole preasureg wire recorded by Morgantoun Energy Technology Cenrer, and these were conglotent with the presarea given in F1g. 3.

The infection perlod is clearly vielble in the Hell a pressures, followed by very fast pressure drop to the range of 100 pel. It remalned there throughout the reat of che experiaent. Minor lluctuations in the pressure occurred during this lucter prilod, and the preseure was controlled anually by adifylng the flow rate frow the vell.

The preseure in Well C (che old production well) rose ctedily a nicrogen was injected, then proceeded to fall as the injectlor. well wat backproduced. Signlficant fluctuatione In Hell C'. presiure occurted poradically, Indicating the occurrunce of the leak deccrlbed earller. The slow preagure rloes indicate the re-sealing of the vell and che tewporary diolnation of the leak.

Well B'. preasure trace nerely shows. Etealy, chough racher ol nor, rlee chroughout the duration of the experloent. The winor nature of thls preasure rlee Indicateq the lack of eny cort o' direci connectlon between Wella $A$ and $C$ and Hell $B$.

\section{N1trogen composition dara}

The percentapes of the nitrugentracer In the three bace at the veltheads are presented in Fis. 4. It can be readily ohnerved that there la merked atructure in the data, and this augurs vell for - Ignlficont analyele.

FUTURE HORK

The ecape in now set for enalyele of the dote. romputer cudes have been developed for analyzlng date of chle type. besed on carefully formulated athemalical wodele. The detalled interpretation requires atching the reaulta from theer ondela to the dnta preenced above. The rock in characterleed by tuo beelcally different furas of porostey and pemenbllity. One of thene deccriben the potentlally andoctroplc and non-homogenrous network of tractures that Interlacen about the unframtured blocks. The other deccibes the propertlee of the blocks chereselves.

The fundamental atructure of our aodela te baed on the princlples of mane. oomentum and energy trameport of tracer-laden cospreselble gan through porime and permeable aterlal. For ench new Investlgation a nall number of parametera mint be specifled to characterize the rock. In part these can be measured by an analysio of samp?es from cores or outcrops. In part they must be derlued by a careful comparioon of caliulacional results with fleld-teat data. When the daca and calculatioral results closely wach, then the paraweters required $f$ or the wechtng calcularlons can be considered to characterize the roch properties. Moreover, the results of the macching calculation will yield an abundance of Informetion that 1s unovallable from fleld weasurements.

\section{ACKNOWLDG:ENTS}

We gratefully ecknouledge the cechnical support of Mr. Karl-Helnz Frohne of DOE' Morgantown Energy Technology Center.

\section{REFERENCES}

1. Elkins, Lincoln F., "Deterwination of Fracture Vold Volume in Devonian Sliale Ualing Injection of Two Tracer Ganes." sohlo Perroleur Compan. comunication ent to rulf Universities Research Consortium and to Gas Researich Institute. Sept. 29, 1978 .

2. Schwiecerint, Joreph $F$. , "Devonian Shales of Oh:o and The1r Eaccern and Sourhern Equivalenti," Morgantown Energy Technology Center report METC/CR-79/2, January 1)79, PP. 31-33.

3. Sclence Applicatione, Ine., "A Reservol Englneering Study for the offset Hell Test Frogram," Morgantown, Heat Virginia trancli, Deceuber 19,1980, p. 27

4. Alam, Javad, private commulcation, SA!, Morgantoun, Hest VIrginia, June 198!. 


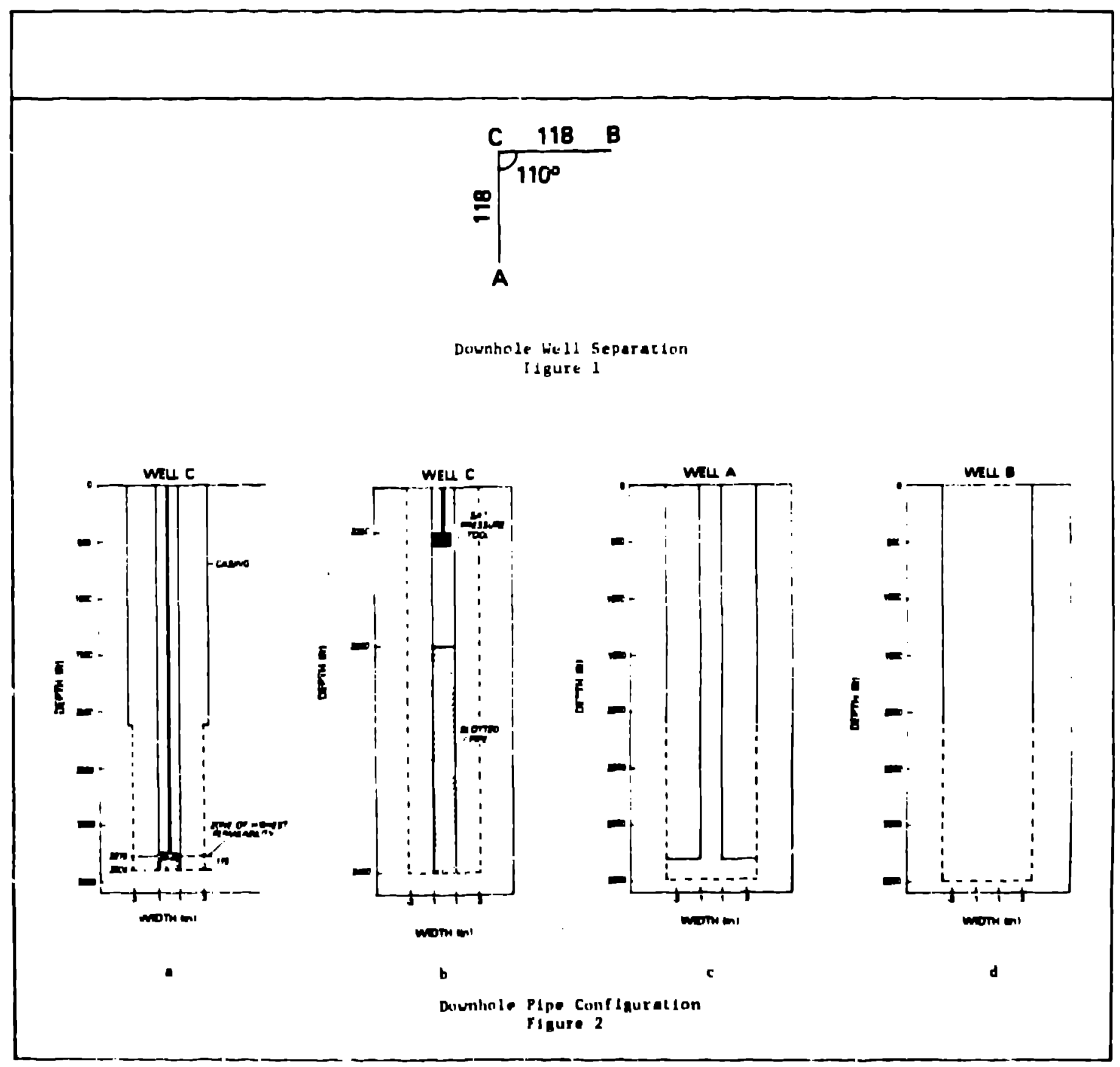




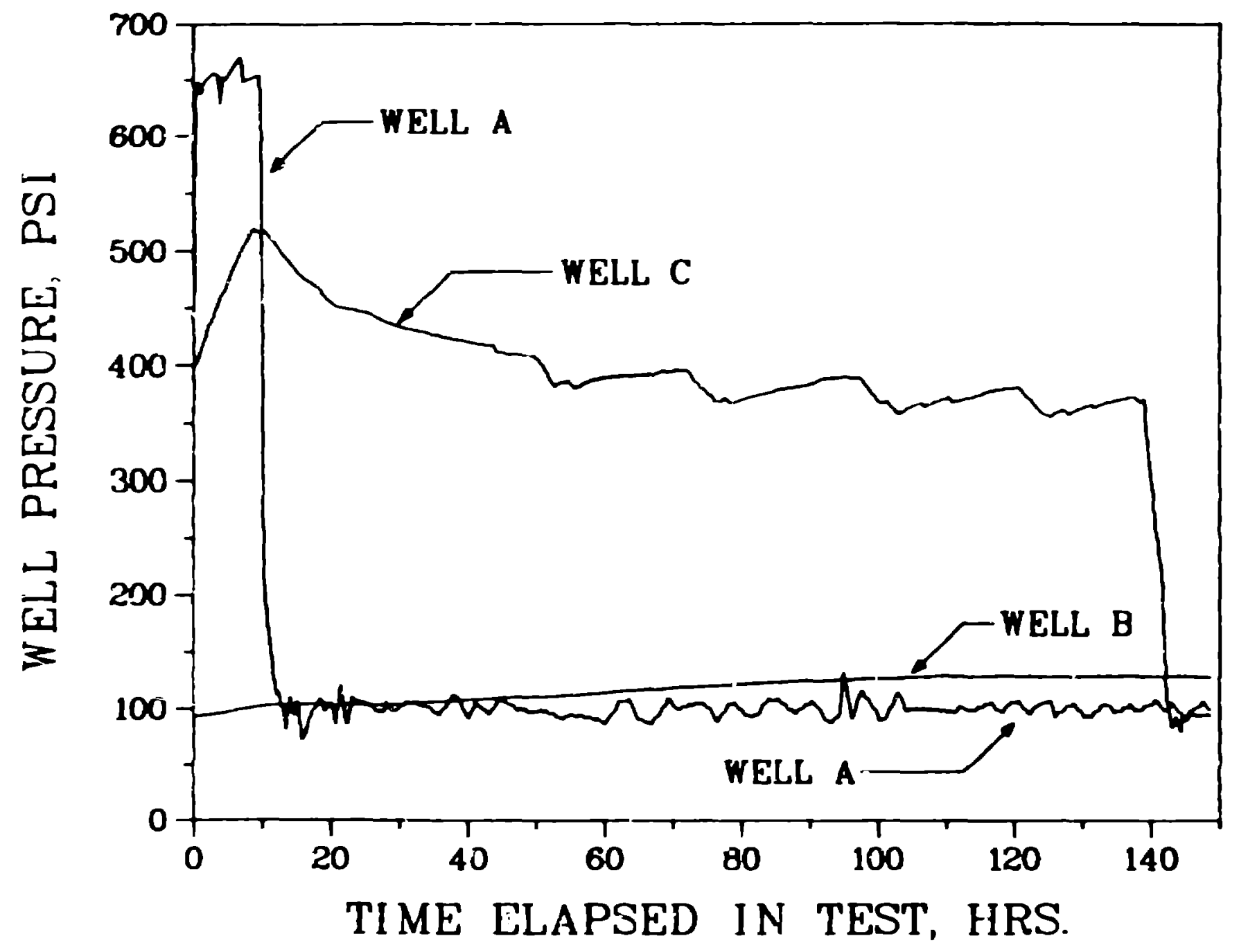

FIClRF 3. Wellhead Pressures 


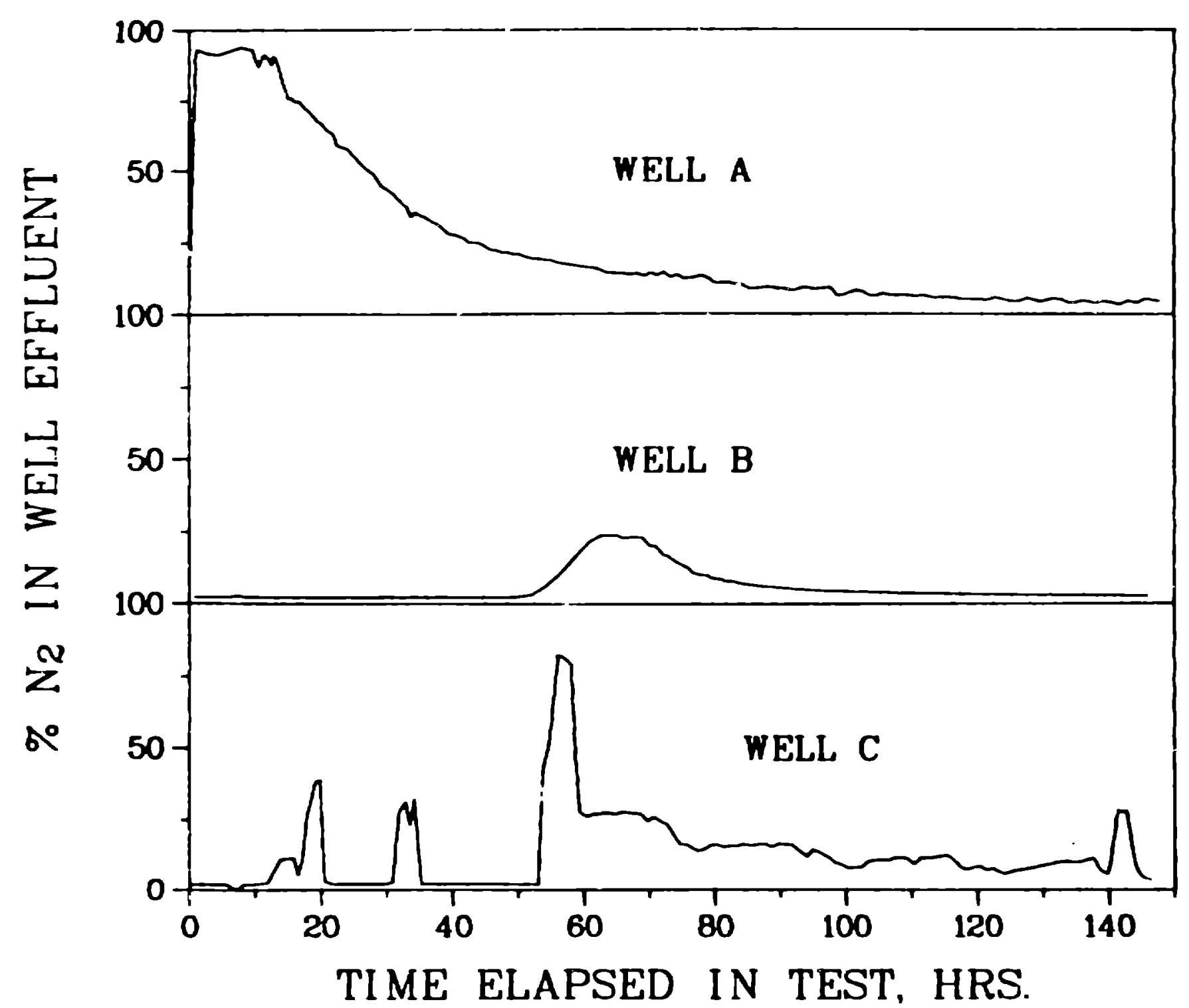

FIGURF 4. Tracer Concentration 